\title{
Investigating the effects of customer-based brand equity on turnover intentions with mediating effect of customer citizenship behavior
}

\author{
Mohsin Raza ${ }^{a^{*}}$, Salniza Salleh ${ }^{a}$, Beenish Tariq ${ }^{b}$, Raed Saud Altayyar ${ }^{\mathrm{c}}$ and Hasnizam Shaari ${ }^{\mathrm{a}}$
}

${ }^{a}$ Universiti Utatra Malaysia, Malaysia

${ }^{b}$ National University of Sciences and Technology, Islamabad, Pakistan

${ }^{c}$ Majmaah University, Saudi Arabia

C H R O N I C L E

\begin{tabular}{l} 
Article history: \\
Received: June 242019 \\
Received in revised format: July \\
282019 \\
Accepted: September 3, 2019 \\
Available online: \\
September 3, 2019 \\
\hline Keywords: \\
Customer citizenship behavior \\
Turnover intentions \\
Customer-based brand equity
\end{tabular}

\section{A B S T R A C T}

This study addresses the issue of rising turnover intention in Pakistan's aviation industry and provides a theoretical foundation for lowering the turnover intention with the help of consumer citizenship behavior (CCB) and consumer-based brand equity by using the S-O-R theory. The data is collected with the help of structured personally administered questions following the intercept approach. Three most frequently used international airports which are located at Lahore, Karachi and Peshawar are targeted for data collection and total of 388 Pakistani flyers who traveled to international destinations participate in the survey. In addition, this study uses SmartPLS 3.2.7 for data analysis with the help of a two-stage approach. The results state that CBBE had a significant effect on $\mathrm{CCB}$ and $\mathrm{CCB}$ had a significant impact on turnover intentions. Furthermore, CCB plays the role of an important mediator for the effect of customer based brand equity (CBBE) on turnover intention. These results enhance existing literature about lowering the turnover intention with the help of CCB and CBBE in aviation industry of Pakistan. The study also highlights that managers and practitioners should improve customer engagement for exhibiting CCB to reduce customer turnover intentions in the aviation industry.

\section{Introduction}

The essence of a product and service brands' triumph lies in its customers. The brands which fail to put their fingers on the pulse of true customers' needs on right time ends up with loss of significant count of customers (Ali et al., 2015). Since customers are the lifeblood of running a business, the brands develop and promote customer-oriented strategies to reduce their customers' loss and their turnover intentions (Halbesleben \& Buckley, 2004). Intensive competition, the upsurge of airline industry challenges, significant changes in expectations, demands and behavior of the customer in services industry of Pakistan specifically aviation industry, urged the airlines to endeavor for lowering customers' turnover (Ali et al., 2015). According to Iqbal and Badshah (2016), the aviation industry of Pakistan is experiencing a tremendous growth rate of 5\% each year and the number of customers raised from 8.5 million to 11.9 million over the period 2010-2015. On the other hand, Pakistan international airline (PIA) is facing unexpected customers turnover to foreign carriers. The local flying carrier of Pakistan lost their $13 \%$ of customer who switched to foreign flying carriers (Iqbal \& Badshah, 2016). Such customers' turnover from local flying carriers to foreign carriers alerted the scholars and practitioners to look for a suitable solution (Ali et al., 2015). It is necessary to strengthen relationship of local aviation industry with customers and their participation for the betterment of brand. Therefore, local aviation brands understands customers as their core strength for competitive advantage (Ali et al., 2012). Marketing literature comprehends the worth of customers participation and argued customers as an inseparable part of services (Lusch \& Vargo, 2006; Vargo \& Lusch, 2005). Specifically, volunteer participation or customer citizenship behavior (CCB) are crucial for the smooth functioning and long-term sustainability of a services brand (Chan et al., 2017). CCB is a prosocial behavior of customers for information sharing and well-being of brands and other customers (Wu et al., 2017). Developing citizenship behavior in customers helps brand for managing the customer-brand relationship, reducing turnover

* Corresponding author.

E-mail address: mohsinraza006@gmail.com (M. Raza) 
intentions in customers and enhancing brands' sustainability (Tung et al., 2017). That is why the understudied phenomenon of CCB has got heated debates among practitioners (Nagy \& Marzouk, 2018). Due to such richness of construct, marketing literature has highlighted the importance, applicability, and significances of CCB in the aviation industry (Lishan et al., 2014). In the aviation industry, services being delivered in a shared environment where customers share their time, space and equipment collectively. CCB foster customers to guide other customers to enhance their service experience (Kim \& Choi, 2016). In addition, CCB encourage customers to support their fellow customers, providing feedback to brands to improve their services, being an advocate of brand and tolerating an undesirable situation which ultimately improve market share, sales and sustainability of brands and also lower the turnover intentions of customer (Revilla-Camacho et al., 2015). This prosocial support of customers also encourages other customers to adopt this behavior which is highly beneficial for brands (Zhu et al., 2016). Therefore, CCB is considered as the most suitable approach for local aviation industry of Pakistan to manage its customer-brand relationships and lowering turnover intentions of customers.

Marketing literature has been elaborated brand relationship as a vital predictor to generate citizenship behavior in customers of aviation industry (Lishan et al., 2014). Brand relationships and more specifically brand equity is positively related to CCB (Balaji, 2014). Customer based brand equity (CBBE) includes awareness/association, brand loyalty and perceived quality (Yoo \& Donthu, 2001). Prior studies have been highlighted that brand awareness/association, brand loyalty, and perceived quality influence encourage customers to adopt citizenship behavior (Abolfathi et al., 2013; Anaza \& Zhao, 2013; Zhang \& Chen, 2017). The mentioned substantial evidence supports the role of CBBE in predicting CCB. In addition, marketing literature indicates that customer citizenship lower the tendency of customers' turnover and argued CCB as a key predictor to influence turnover intentions of customers (Revilla-Camacho et al., 2015). Therefore, this study posits CCB as mediator between CBBE and customer turnover intention.

\section{Literature Review}

\subsection{Turnover intentions}

Customers are key resources and inseparable part of the services brand (Vargo \& Lusch, 2005). When customers' associations with a brand decreases then they switch to competing brands (Mosavi et al., 2018). Customer turnover intentions bring adverse effects on brands' survival, decrease sales, lower profitability and sustainability in long run (Han \& Sean, 2015). Customer turnover in local aviation industry resulting in inadequate profits, loss of market share, harming competitive abilities and increasing challenges for local flying carrier's survival (Ali et al., 2015). Therefore, brands prefer to adopt customeroriented approaches and engage customers in citizenship behavior to lower the turnover intentions of customers (RevillaCamacho et al., 2015).

\subsection{Customer Citizenship Behavior}

Customer citizenship behavior (CCB) is customers' volunteer actions to assist other customers and support the brands (Nagy \& Marzouk, 2018). Whereas, customers' engagement in citizenship behavior is not obligatory but it is being adopted by customers to assist brand and fellow customers (Kim \& Choi, 2016). According to Yi and Gong (2013), CCB consists of four indicators that are helping behavior, advocacy, feedback, and tolerance. Helping behavior referred as customers' help to brand and fellow customers in service delivery. Advocacy refers to spreading positive word of mouth and protecting the brand from negative comments. Feedback refers to customers' response to brands for their services. Tolerance is reffered as the capacity of the customers to bear unwanted situation while service delivery. Marketing literature highlights CCB as crucial for brands to maintain their relationship with customers (Tung et al., 2017). CCB develop positive behavior in customers, improve market share, profits, sales and lower the customer turnover intentions (Revilla-Camacho et al., 2015). It helps the brand retain customers for long time and enhance brand performance (Jaakkola \& Alexander, 2014). Consequently, CCB has become a hot topic of this era among scholars and practitioners (Nagy \& Marzouk, 2018).

\subsection{Customer based brand equity}

Customer based brand equity (CBBE) is one of the key concerns of brands. Brand equity is set of assets associated with the brand and provides value to the customer (Aaker, 1991). According to Yoo and Donthu (2001), CBBE consists of brand loyalty, brand association, and perceived quality. Brand loyalty is explained as the level of customers' attachment towards the brand (Aaker, 1991). Brand association is explained as customers' associations with services (Severi \& Ling, 2013). In addition, It is also referred to customers' awareness to recognize a brand in presence of competitive brands (Seo \& Park, 2018). Perceived Quality is explained as the influence of customers on brand either negative or positive (Aaker, 1991). Prior studies have highlighted brand loyalty, brand awareness and perceived quality as predictors of CCB. Brand loyalty encourages customers to adopt CCB to assist brand and customer to smoothening the functions of brand (Anaza \& Zhao, 2013). Brand awareness encourages customers to adopt citizenship behavior for the brand with whom they are associated (Zhang \& Chen, 2017). Perceived quality of a brand also foster customers to involve in citizenship behavior (Abolfathi et al., 2013). In addition, literature indicated CBBE as important predictor to develop CCB in aviation industry and important strategy to strengthen relationships among brands and customers over the period of time (Lishan et al., 2014; Wu et al., 2017).

\section{Research Objective}

The objective of the current study is threefold. The first objective is managing the customer-brand relationships, more preciously customer-based brand equity (CBBE). The second objective is observing the effect of CCB on customers' turnover 
intentions. The third objective is to operationalize $\mathrm{CBBE}$ and $\mathrm{CCB}$ as first order reflective and second-order formative construct. Moreover, current study makes two major contributions. First, this study tests the effect of CBBE on customers' turnover intentions through the mediation of consumer citizenship behavior. Secondly, the research model tests the effect of CCB on customers' turnover intentions in Pakistan's aviation industry.

\subsection{Conceptual Framework}

This study incorporates $\mathrm{CBBE}$ as an independent variable, $\mathrm{CCB}$ as mediator and turnover intentions as the dependent variable. Furthermore, this study investigates how CCB mediates the relationship between CBBE and customers turnover intentions using Preacher and Hayes (2004) mediation approach. This framework is supported by stimulus-organism response theory which explains that when an organism triggered by stimuli, it generates a response (Russell \& Mehrabian, 1977). In this study, $\mathrm{CBBE}$ act as a stimulus, $\mathrm{CCB}$ as an organism and turnover intentions as a response. In addition, this study addressed the lack of empirical research in the aviation industry to enhance the literature on lowering turnover intention with the help of $\mathrm{CCB}$ and CBBE.

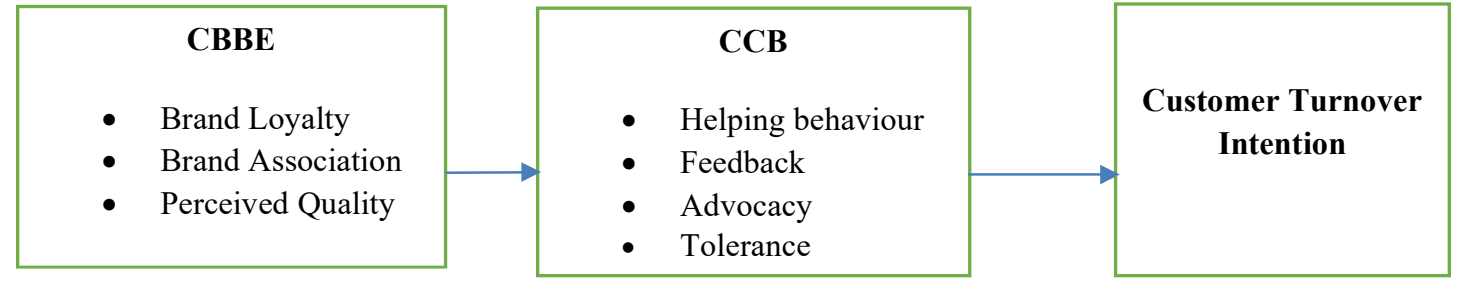

Hypothesis 1 (H1). CBBE has a significant effect on CCB.

Hypothesis 2 (H2). CCB has a significant effect on customer turnover intention.

Hypothesis 3 (H3). CCB mediates the effect of CBBE on customer turnover intention.

\subsection{Research Methodology}

This study uses a multi-stage clustered sampling technique for determination of sample size. The population inside the cluster is heterogeneous and among clusters is homogenous. According to Sekaran and Bougie (2016), the multi-stage clustered sampling technique is considered appropriate for this study. Subsequently, the airport intercept approach is used to target customers. There are twelve major international airports in Pakistan which are in four provinces of Pakistan and cover the customer traffic from all over the world. That is why, each of the provinces is considered a cluster. In addition, according to Pakistan Civil Aviation Authority (2017), 14,485,950 customers take international flights through these airports. However, the customer traffic from these airports is as followed. i.e. $63 \%$ of these customers traveled from airports located in province Punjab, 27\% customers traveled via airports located in province Sindh, 10\% customers traveled via province KPK and around 1\% customers from province Baluchistan. Since most of the customers travel through airports in Punjab, Sindh, and KPK so data is collected from Lahore (Punjab), Karachi (Sindh), and Peshawar (KPK) due to the highest customer walk in based on CIA report (Pakistan Civil Aviation Authority, 2017). Table 1 shows the proportions calculated for 500 questionnaires based on CIA report.

Table 1

Determination of Sample Size for each cluster

\begin{tabular}{lccc}
\hline Province & Customer Traffic & Percentage (\%) & Sample Size \\
\hline Punjab & $9,175,797$ & 63 & 315 \\
Sindh & $3,891,704$ & 27 & 135 \\
KPK & $1,418,449$ & 10 & 50 \\
\hline Grand Total & $14,485,950$ & 100 & 500 \\
\hline
\end{tabular}

\subsection{Data Collection Procedure}

Keeping in consideration the objectives of this study, survey technique has been used for data collection. For this purpose, the data was collected from the customers who traveled through international airports as mentioned earlier (Table 1) from Lahore, Karachi, Peshawar by distributing 315, 135 and 50 questionnaires respectively. Most of the respondents were frequent flyers who flew regularly. Before conducting the survey, permission was granted from the airport authorities. The survey forms were distributed to the customers in the waiting lounges via face to face requests using the intercept approach. Two enumerators were hired and trained for data collection. The researchers collected data from Lahore, however, enumerators collected data from Karachi and Peshawar. The researchers and enumerators visited airports based on international flight schedules. The data was gathered from every third customer who entered the waiting lounge. The researchers contacted the customer and requested to participate in the survey. The questionnaire is given to the customers who were willing to fill out the questionnaire and requested to return the questionnaire while leaving the waiting lounge. To improve the participation and reduce the rate of refusal the respondents were offered a keychain upon returning the filled questionnaire. The survey questionnaire was personal-administered and consists of three sections. 
Section (A) consists of filter questions including the question about the frequency of the flights and the reason for traveling abroad.

Section (B) consists of questions related to the customer's understudy which are customer based brand equity, customer citizenship behavior, and turnover intentions

Section (C) consists of respondents' profile which includes the questions related to age, education, marital status, income, and gender.

A total of 500 questionnaires were distributed whereby 387 questionnaires were returned recording a response rate of $77.4 \%$ which is consistent with the past studies in Pakistani airline (Saleem et al., 2017).

\subsection{Measures}

This study adapted the customer based brand equity (CCBE) instrument from Yoo and Donthu (2001) who originally developed this scale with the help of three dimensions: brand loyalty (three items), perceived quality (two items) and brand awareness (five items). Most of the previous studies operationalized this scale as a reflective scale (Anselmsson et al., 2014; Salehzadeh et al., 2018). However, CBBE is a summative judgment based on three dimensions which dictate it to be a secondorder formative construct. This operationalization gained the support of Jarvis et al. (2003) and Hair et al. (2017) according to which when the items/sub-dimensions cannot be interchanged and every item/sub-dimension captures a unique part of the construct, the construct is formative. Since brand loyalty, perceived quality and brand awareness are not interchangeable, this study operationalized this scale as first order reflective and second-order formative. The scale for CCB was adapted form Yi and Gong (2013) which consists of four dimensions: feedback (three items), advocacy (three items), helping behavior (four items) and tolerance (three items). Since CCB is composed of these four dimensions and the dimensions are non-interchangeable (Hair et al., 2017; Jarvis et al., 2003) hence to avoid model misspecification the scale is operationalized as first order reflective and second-order formative. The scale for turn over intention is adapted from Revilla-Camacho et al. (2015) which is a uni-dimensional scale with five items. It is operationalized as a reflective construct in this study. All the items were measured by using 7 Point Likert scale from 1 being strongly disagreed to 7 strongly agreeing. Before finalizing the questionnaire, a pre-test was conducted by using debriefing method to eliminate potential problems with questionnaire design, and the comprehensiveness of the instructions and statements (Bazera, 1996; Hunt et al., 1982). In addition, common method variance is considered not an issue because of the presence of both reflective and formative constructs in the instrument (Hair Jr, Hult, Ringle, \& Sarstedt, 2016; Hiram et al., 2015).

\subsection{Respondents Profile}

The demographic profile of respondents ranged from 15 to 55 years and more. The results show that most of the respondents belong to the age group of 26-35 years, 15 to 25 years and $36-45$ years representing $34.4 \%, 25.3 \%$ and $23.5 \%$ of the total sample respectively. The remaining $10.9 \%$ and $5.9 \%$ represents an age group of $46-55$ years and more than 55 years. In addition, the respondents' profile highlighted that respondents were well educated where $52.7 \%$ and $39.3 \%$ of the total sample holds master and bachelor's degrees respectively. In addition, more than $50 \%$ of respondents belong to income group ranging from PKR 31,000- more than PKR. 60,000. Subsequently, most of the respondents were married representing 59.2\% of the sample. Moreover, there were $70.3 \%$ of males in the sample while the rest of the respondents were females and $60 \%$ of them were married. The respondents' profile is given in Fig. 1.

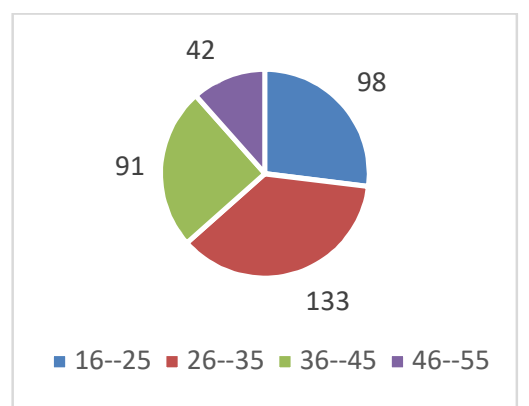

Age

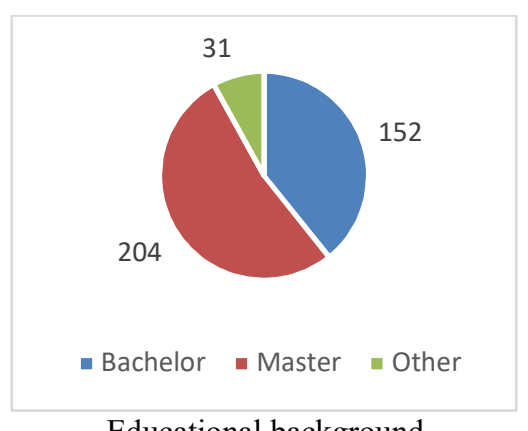

Educational background

Fig. 1. Personal characteristics of the participants

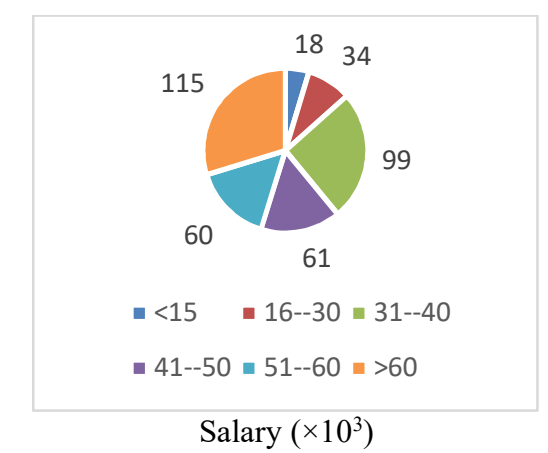

Salary $\left(\times 10^{3}\right)$

\subsection{Data Analysis}

This study consists of both reflective and second-order formative constructs (higher order constructs), so based on the suggestion of Becker et al. (2012) sequential latent variable score method with the help of smart PLS 3.2.7 has been employed for data analysis. According to Hair Jr et al. (2016), it is necessary to specify the model operationalization to avoid the type I and type II errors (Diamantopoulos \& Winklhofer, 2001; Edwards \& Bagozzi, 2000). Hence, this study considered CBBE and $\mathrm{CCB}$ as reflective formative higher order constructs and TOI as reflective first order construct. Following the recommended two-stage analytical procedures by Anderson and Gerbing (1988), this study tested the measurement model (validity and reliability of the measures) followed by an examination of the structural model (testing the hypothesized relationships) (see 
Hair et al. 2014; Ramayah et al. 2011, 2013). The measurement model evaluation criteria for reflective and formative constructs are different (Hair Jr et al., 2016). Hence to access the internal consistency and convergent validity of reflective constructs, outer loadings, average variance extracted (AVE), composite reliability (CR) are reported. In addition, discriminant validity (DV) is assessed using Fornell and Larcker (1981) criterion. However, for formative constructs multi-collinearity with the help of variance inflation factor (VIF), outer weights significance after bootstrapping is reported. To test the significance of the path coefficients and the loadings, a bootstrapping method was used (Hair et al. 2014).

\subsection{Assessment of Reflective Measurement Model}

The results of Table 2 show that outer loadings of all the reflective constructs are above the minimum threshold of 0.50 as suggested by Hair et al. (2016) and achieved the internal consistency. Similarly, the results of composite reliability (CR) show that all the reflective constructs exhibit reliability with possessing the CR above .70 (Hair et al., 2016). Furthermore, the constructs demonstrate enough convergent validity which is well above the threshold of .50 and reveal that all the items explain more than $50 \%$ of the variance in each respective construct (Hair et al., 2013).

Table 2

Internal consistency and Convergent Validity of Reflective Constructs

\begin{tabular}{|c|c|c|c|c|}
\hline First Order Reflective Constructs & Item & Loadings & AVE & $\mathbf{C R}$ \\
\hline \multirow[t]{3}{*}{ Brand Loyalty (BL) } & BL1 & 0.895 & \multirow[t]{3}{*}{0.842} & \multirow[t]{3}{*}{0.941} \\
\hline & BL2 & 0.937 & & \\
\hline & BL3 & 0.921 & & \\
\hline \multirow[t]{2}{*}{ Perceived Quality (PQ) } & PQ1 & 0.945 & \multirow[t]{2}{*}{0.898} & \multirow[t]{2}{*}{0.946} \\
\hline & PQ2 & 0.950 & & \\
\hline \multirow[t]{5}{*}{ Brand Awareness (BA) } & BA1 & 0.827 & \multirow[t]{5}{*}{0.716} & \multirow[t]{5}{*}{0.926} \\
\hline & BA2 & 0.876 & & \\
\hline & BA3 & 0.847 & & \\
\hline & BA4 & 0.849 & & \\
\hline & BA5 & 0.829 & & \\
\hline \multirow[t]{3}{*}{ Feedback (FB) } & FB1 & 0.865 & \multirow[t]{3}{*}{0.774} & \multirow[t]{3}{*}{0.911} \\
\hline & FB2 & 0.889 & & \\
\hline & FB3 & 0.886 & & \\
\hline \multirow[t]{3}{*}{ Advocacy (ADV) } & ADV1 & 0.903 & \multirow[t]{3}{*}{0.792} & \multirow[t]{3}{*}{0.920} \\
\hline & ADV2 & 0.915 & & \\
\hline & ADV3 & 0.851 & & \\
\hline \multirow[t]{4}{*}{ Helping Behavior (HB) } & HB1 & 0.839 & \multirow[t]{4}{*}{0.731} & \multirow[t]{4}{*}{0.916} \\
\hline & HB2 & 0.881 & & \\
\hline & HB3 & 0.879 & & \\
\hline & HB4 & 0.820 & & \\
\hline \multirow[t]{3}{*}{ Tolerance (T) } & $\mathrm{T} 1$ & 0.903 & \multirow[t]{3}{*}{0.727} & \multirow[t]{3}{*}{0.889} \\
\hline & $\mathrm{T} 2$ & 0.859 & & \\
\hline & T3 & 0.792 & & \\
\hline \multirow[t]{5}{*}{ Turnover Intention (TOI) } & TOI1 & 0.847 & \multirow[t]{5}{*}{0.766} & \multirow[t]{5}{*}{0.942} \\
\hline & TOI2 & 0.896 & & \\
\hline & TOI3 & 0.907 & & \\
\hline & TOI4 & 0.890 & & \\
\hline & TOI5 & 0.833 & & \\
\hline
\end{tabular}

The discriminant validity is assessed is using Fornell and Larcker (1981) criterion whereby the results in Table 3 show that all the square roots of AVE of each construct are larger than the correlation estimate of the constructs. Hence, discriminant validity is also established for all the reflective constructs.

Table 3

Discriminant Validity: Fornell and Larcker Criterion (1981)

\begin{tabular}{llllllll}
\hline & HB & ADV & BA & BL & FB & PQ & \\
\hline HB & $\mathbf{0 . 8 5 5}$ & & & & & & \\
ADV & 0.769 & $\mathbf{0 . 8 9 0}$ & & & & \\
BA & 0.794 & 0.808 & $\mathbf{0 . 8 4 6}$ & & & \\
BL & 0.754 & 0.773 & 0.776 & $\mathbf{0 . 9 1 8}$ & & \\
FB & 0.744 & 0.786 & 0.755 & 0.721 & $\mathbf{0 . 8 8 0}$ & $\mathbf{0 . 9 4 8}$ & \\
PQ & 0.673 & 0.745 & 0.736 & 0.799 & 0.704 & 0.655 & \\
T & 0.798 & 0.756 & 0.777 & 0.714 & 0.713 & $\mathbf{0 . 8 5 3}$ \\
TOI & 0.728 & 0.749 & 0.773 & 0.804 & 0.724 & 0.772 & 0.707 \\
\hline
\end{tabular}

Note: Diagonal elements highlighted in bold represent the square root of AVE. Off-diagonal elements are bivariate correlations between the constructs.

\subsection{Assessment of Formative Second Order Constructs}

Table 4 exhibits the assessment of formative second-order constructs. All the VIF values for each of the formative constructs are well below the threshold of 5 (Diamantopoulos \& Siguaw, 2006), depicting that all the constructs are different from each other and cannot be interchanged. In addition, the significance of outer weights (after bootstrapping of 5000 samples) also 
reveal that all the first order constructs are significant and relevant for their respective second-order formative constructs. Hence, second-order formative constructs also possess convergent validity.

Table 4

Outer Weights Path Significance and Multi-collinearity

\begin{tabular}{|c|c|c|c|c|c|}
\hline Paths & B & SD & T Value & P Values & VIF \\
\hline $\mathrm{BL} \rightarrow \mathrm{CBBE}$ & 0.317 & 0.049 & 6.460 & 0.000 & 3.524 \\
\hline $\mathrm{PQ} \rightarrow \mathrm{CBBE}$ & 0.168 & 0.048 & 3.490 & 0.000 & 3.052 \\
\hline $\mathrm{BA} \rightarrow \mathrm{CBBE}$ & 0.591 & 0.044 & 13.509 & 0.000 & 2.775 \\
\hline $\mathrm{FB} \rightarrow \mathrm{CCB}$ & 0.237 & 0.059 & 3.987 & 0.000 & 3.047 \\
\hline $\mathrm{ADV} \rightarrow \mathrm{CCB}$ & 0.388 & 0.055 & 6.995 & 0.000 & 3.515 \\
\hline $\mathrm{HB} \rightarrow \mathrm{CCB}$ & 0.275 & 0.062 & 4.422 & 0.000 & 3.555 \\
\hline $\mathrm{T} \rightarrow \mathrm{CCB}$ & 0.201 & 0.056 & 3.614 & 0.000 & 3.249 \\
\hline
\end{tabular}

\subsection{Assessment of Structural Model}

Before assessment of structural model, it is necessary to check the multi-collinearity of the inner model. Table 6 shows that VIF values of the inner model are well below the threshold of 5 (Diamantopoulos \& Siguaw, 2006). Table 6 also illustrates the results of the hypothesis by assessing the $\mathrm{P}$ values and path coefficients after bootstrapping procedure with 5000 subsamples. All the direct relations are found to be significant and positive $\left(\mathrm{H}_{1}\right.$ : $\left.\mathrm{CBBE} \rightarrow \mathrm{CCB}, \beta=0.902, \mathrm{p}<0.00\right)$ and $\left(\mathrm{H}_{2}\right.$ : $\mathrm{CCB} \rightarrow \mathrm{TOI}, \beta=-0.804, \mathrm{p}<0.01)$ and supported the hypotheses. In addition, Table 6 assessed the coefficient of determination $\left(\mathrm{R}^{2}\right)$, the effect size $\left(f^{2}\right)$ as well as the predictive relevance $\left(\mathrm{Q}^{2}\right)$ of exogenous variables on an endogenous variable in this study. The results suggest that $\mathrm{R}^{2}$ value for $\mathrm{CCB}$ is 0.813 suggesting that $\mathrm{CBBE}$ explains $81.3 \%$ variance in $\mathrm{CCB}$. Similarly, the $\mathrm{R}^{2}$ value for TOI is 0.646 , suggesting that $\mathrm{CCB}$ explains $64.6 \%$ variance in TOI. Subsequently, $\mathrm{Q}^{2}$ vales for $\mathrm{CCB}=0.622$ and TOI $=0.625$ demonstrate that the $\mathrm{CBBE}$ had enough predictive capacity over $\mathrm{CCB}$ and $\mathrm{CCB}$ had enough predictive capacity for TOI as suggested by Hair et al. (2013). Likewise, the $f^{2}$ values reveal that CBBE had a large effect on CCB $\left(f^{2}\right.$ $=4.339)$ and CCB also had a large effect on TOI $\left(f^{2}=1.826\right)$ (Hair et al., 2017).

Table 5

Direct Paths Assessment

\begin{tabular}{|c|c|c|c|c|c|c|c|c|}
\hline Paths & B & SD & T Values & P Values & VIF & $\mathbf{R}^{2}$ & $\mathbf{Q}^{2}$ & $f^{2}$ \\
\hline $\mathrm{CBBE} \rightarrow \mathrm{CCB}$ & 0.902 & 0.012 & 74.759 & 0.000 & 1.00 & 0.813 & 0.622 & 4.339 \\
\hline $\mathrm{CCB} \rightarrow \mathrm{TOI}$ & -0.804 & 0.023 & 35.406 & 0.000 & 1.00 & 0.646 & 0.625 & 1.826 \\
\hline
\end{tabular}

\subsection{Mediation Analysis}

As suggested by Hair et al. (2016) and Hayes and Preacher (2010) this study has used a bootstrapping method for analyzing the mediation with a biased corrected confidence interval. According to the results given in Table 6, CCB plays the role of significant mediator between $\mathrm{CBBE}$ and TOI $\left(\mathrm{H}_{3}\right.$ : $\mathrm{CBBE} \rightarrow \mathrm{CCB} \rightarrow$ TOI, $\left.\beta=-0.725, \mathrm{p}<0.00\right)$, hence supported $\mathrm{H}_{3}$.

Table 6

Mediation Analysis

\begin{tabular}{lcccccc}
\hline Mediation Path & B & SD & T Value & P Values & LLCI (2.5\%) & ULCI (97.5\%) \\
\hline CBBE $\rightarrow$ CCB $\rightarrow$ TOI & -0.725 & 0.028 & 25.684 & 0.00 & 0.661 & 0.772 \\
\hline
\end{tabular}

\section{Conclusion}

The purpose of this paper was to provide a better understanding of CCB and its importance in the aviation industry. Moreover, this model helped in explaining the implications of branding elements to minimize customers turnover. This study fills the existing gap in the literature and provides a solution for customer turnover for the aviation industry. Furthermore, this study provides deep insights towards the mediation effect of CCB. Literature revealed that rare studies had dealt with CCB as a mediating variable, so it has been a worthy contribution towards the body of knowledge. Moreover, this study also linkages CBBE to the turnover intention with the mediation of CCB which is rarely tested by literature and proposed framework of study in hand. This study has chosen the aviation sector and data is collected from passengers in waiting lounges and study has been confirming the significant impact of all hypothesis.

\subsection{Managerial Implications}

From a managerial perspective, this study highlights the importance of customers participation in service delivery processes and the relationship of customers with brands. Customer volunteer participation helps the brand raise its market share, profitability, and sales. Therefore, brands should understand the vital role of customers for better performance. Moreover, brands should maintain good relationships with customers to lower their turnover rate. Simultaneously, the communication channel 
should be clear between customers and employees to provide appropriate service. Brands should facilitate customer to customer communication which foster customers to adopt CCB because interaction requires a friendly environment where services are being provided. Furthermore, the aviation industry should focus on CCBE to keep their customers engaged with the brand. Such engagement of customer will foster them to show CCB. The study in hand suggested that CCB lesser the turnover intentions in the customers. CCB encourages the customer to stay loyal with aviation brands for a longer period which help brand towards sustainability.

\subsection{Limitation and future studies}

This study is not free from certain limitations. In this study, customers have been asked about the adoption of CCB through the implication of branding elements. For future studies, safety practices and AIRQUAL also can be considered to develop $\mathrm{CCB}$ in the aviation sector. Other branding elements of relationship marketing e.g. brand loyalty, brand trust, and brand identification can be studied in the services sector as predictors of CCB. Moreover, this study can be applied in other services sectors to predict customers' behaviors. Marketer and scholars will be encouraged to develop other models to generate CCB in customers.

\section{References}

Aaker, D. A. (1991). Managing brand equity. The Free Press.

Abolfathi, A., Tollabi, Z., \& Pourashrf, Y. A. (2013). The study of the relationship between perceived quality of electronic services and melli bank customers ' citizenship behavior in ilam province. European Online Journal of Natural and Social Sciences, 2(3), 1159-1168.

Ali, F., Dey, B. L., \& Filieri, R. (2015). An assessment of service quality and resulting customer satisfaction in Pakistan International Airlines findings from foreigners and overseas Pakistani. International Journal of Quality \& Reliability Management, 31(1), 110-124.

Ali, F., Khan, A. S., \& Rehman, F. A. M. S. ul. (2012). An assessment of the service quality using gap analysis: A study condusted at Chitral, Pakistan. Interdisciplinary Journal of Contemporary Research in Business, 4(3), 259-266.

Anaza, N., \& Zhao, J. (2013). Encounter-based antecedents of e-customer citizenship behaviors. Journal of Services Marketing, 27(2), 130-140.

Anselmsson, J., Vestman Bondesson, N., \& Johansson, U. (2014). Brand image and customers' willingness to pay a price premium for food brands. Journal of Product \& Brand Management, 23(2), 90-102.

Balaji, M. S. (2014). Managing customer citizenship behavior: a relationship perspective. Journal of Strategic Marketing, 22(3), 222-239.

Bazera, M. (1996). Marketing research for planning, monitoring and marketing design making: Al-Obikan Press, Riyadh.

Becker, J. M., Klein, K., \& Wetzels, M. (2012). Hierarchical latent variable models in PLS-SEM: guidelines for using reflective-formative type models. Long Range Planning, 45(5), 359-394.

Chan, K. W., Gong, T., \& Zhang, R. (2017). Do employee citizenship behaviors lead to customer citizenship behaviors ? The roles of dual identification and service climate. Journal of Service Research. https://doi.org/10.1177/1094670517706159

Diamantopoulos, A., \& Siguaw, J. A. (2006). Formative versus reflective indicators in organizational measure development: A comparison and empirical illustration. British Journal of Management, 17(4), 263-282.

Diamantopoulos, A., \& Winklhofer, H. M. (2001). Index construction with formative indicators: An alternative to scale development. Journal of Marketing Research, 38(2), 269-277.

Edwards, J. R., \& Bagozzi, R. P. (2000). On the nature and direction of relationships between constructs and measures. Psychological methods, 5(2), 155.

Fornell, C., \& Larcker, D. F. (1981). Structural equation models with unobservable variables and measurement error: Algebra and statistics. Journal of Marketing Research, 18(3), 382-388.

Halbesleben, J. R. B., \& Buckley, M. R. (2004). Managing customers as employees of the firm. Personnel Review, 33(3), $351-372$.

Han, H., \& Sean, S. (2015). Customer retention in the medical tourism industry : Impact of quality, satisfaction , trust , and price reasonableness. Tourism Management, 46, 20-29.

Iqbal, T., \& Badshah, M. (2016). Aviation Industry (Vol. 11).

Hair, J. F., Hult, G., \& Christian, M. (2013). A primer on partial least squares structural equation modeling (PLS-SEM). 2013. SAGE Publications, Inc Human Resource Management, 22(1), 34-56.

Hair, J. F., Hult, G. T. M., Ringle, C., \& Sarstedt, M. (2016). A primer on partial least squares structural equation modeling (PLS-SEM): Sage Publications.

Hair, J. F., Sarstedt, M., Ringle, C. M., \& Gudergan, S. P. (2017). Advanced Issues in Partial Least Squares Structural Equation Modeling: SAGE Publications.

Hair Jr, J. F., Hult, G. T. M., Ringle, C., \& Sarstedt, M. (2016). A primer on partial least squares structural equation modeling (PLS-SEM): Sage Publications.

Hayes, A. F., \& Preacher, K. J. (2010). Quantifying and testing indirect effects in simple mediation models when the constituent paths are nonlinear. Multivariate behavioral research, 45(4), 627-660. 
Hiram, T., Chuah, F., Cheah, J., Memon, M. A., \& Yacob, Y. (2015). Revisiting attitude towards advertising, its antecedent and outcome: A two-stage approach using PLS-SEM. International Journal of Economics and Management, 9(2), 150170.

Hunt, S. D., Sparkman, J. R. D., \& Wilcox, J. B. (1982). The pretest in survey research: Issues and preliminary findings. Journal of Marketing Research, 19(2), 269-273.

Jarvis, C. B., MacKenzie, S. B., \& Podsakoff, P. M. (2003). A critical review of construct indicators and measurement model misspecification in marketing and consumer research. Journal of Consumer Research, 30(2), 199-218.

Jaakkola, E., \& Alexander, M. (2014). The role of customer engagement behavior in value co-creation. Journal of Service Research, 17(3), 247-261.

Kim, H. S., \& Choi, B. (2016). The effects of three customer-to-customer interaction quality types on customer experience quality and citizenship behavior in mass service settings. Journal of Services Marketing, 30(4), 384-397.

Lishan, X., Wenxuan, Z., \& Yinmei, P. (2014). Mediation effect of brand relationship quality between airline brand experience and customer citizenship behavior. 11th International Conference on Service Systems and Service Management, ICSSSM 2014 - Proceeding. https://doi.org/10.1109/ICSSSM.2014.6874080

Lusch, R. F., \& Vargo, S. L. (2006). Service-dominant logic: Reactions, reflections and refinements. Marketing Theory, 6(3), 281-288.

Mosavi, S. M., Sangari, M. S., \& Keramati, A. (2018). An integrative framework for customer switching behavior. The Service Industries Journal, O(0), 1-28. https://doi.org/10.1080/02642069.2018.1428955

Nagy, E. S. A., \& Marzouk, W. G. (2018). Factors affecting customer citizenship behavior : a model of university students. International Journal of Marketing Studies, 10(1), 54-70.

Pakistan Civil Aviation Authority. (2017). Pakistan civil aviation authority; major traffic flows by airports during the year Pakistan civil aviation authority; major traffic flows by airports during the year.

Preacher, K. J., \& Hayes, A. F. (2004). SPSS and SAS procedures for estimating indirect effects in simple mediation models. Behavior Research Methods, Instruments, \& Computers, 36(4), 717-731.

Revilla-Camacho, M. Á., Vega-Vázquez, M., \& Cossío-Silva, F. J. (2015). Customer participation and citizenship behavior effects on turnover intention. Journal of Business Research, 68(7), 1607-1611.

Russell, J. A., \& Mehrabian, A. (1977). Evidence for a three factor theory of emotions. Journal of Research in Personality, 11, 273-294.

Salehzadeh, R., Pool, J. K., \& Najafabadi, A. H. J. (2018). Exploring the relationship between corporate social responsibility, brand image and brand equity in Iranian banking industry. Journal of Islamic Accounting and Business Research, 9(2), $106-118$.

Saleem, M. A., Zahra, S., \& Yaseen, A. (2017). Impact of service quality and trust on repurchase intentions-the case of Pakistan airline industry. Asia Pacific Journal of Marketing and Logistics, 29(5), 1136-1159.

Sekaran, U., \& Bougie, R. (2016). Research methods for business; a skill building approach. Wiley.

Seo, E. J., \& Park, J. W. (2018). A study on the effects of social media marketing activities on brand equity and customer response in the airline industry. Journal of Air Transport Management, 66(August 2017), 36-41.

Severi, E., \& Ling, K. C. (2013). The mediating effects of brand association, brand loyalty, brand image and perceived quality on brand equity. Asian Social Science, 9(3), 125-137.

Tung, V. W. S., Chen, P. J., \& Schuckert, M. (2017). Managing customer citizenship behaviour: the moderating roles of employee responsiveness and organizational reassurance. Tourism Management, 59, 23-35.

Vargo, S. L., \& Lusch, R. F. (2005). Evolving to a new dominant logic for marketing. Journal of Marketing, 68(1), 1-17.

Wu, S.-H., Huang, S. C.-T., Tsai, C.-Y. D., \& Lin, P.-Y. (2017). Customer citizenship behavior on social networking sites the role of relationship quality, identification, and service attributes. Internet Research, 27(2), 428-448.

Yi, Y., \& Gong, T. (2013). Customer value co-creation behavior: scale development and validation. Journal of Business Research, 66(9), 1279-1284.

Yoo, B., \& Donthu, N. (2001). <Developing and validating a multidimensional consumer-based brand equity scale.pdf $>$. Journal of Business Research, 52, 1-14.

Zhang, Y., \& Chen, L. (2017). The impacts of website characteristics and customer participation on citizenship behaviors : the mediating role of co-creation experience in virtual brand communities. Advances in Applied Sociology, $151-164$.

Zhu, D. H., Sun, H., \& Chang, Y. P. (2016). Effect of social support on customer satisfaction and citizenship behavior in online brand communities: the moderating role of support source. Journal of Retailing and Consumer Services, 31, 287293.

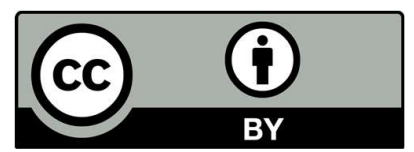

(C) 2020 by the authors; licensee Growing Science, Canada. This is an open access article distributed under the terms and conditions of the Creative Commons Attribution (CCBY) license (http://creativecommons.org/licenses/by/4.0/). 